\title{
Assessment Of The Indoor And Outdoor Mycoflora Of Schools In Jabalpur City, India
}

\author{
Karuna S. Vermaand Prem Shankar Sahu \\ Aeroallergens \& Immunology laboratory, Department of Post Graduate Studies and Research in Biological \\ Science, Rani Durgawati University, Jabalpur -01 (M.P.)
}

\begin{abstract}
A survey for viable fungal spores in the indoor and outdoor environments of 60 school buildings in Jabalpur city was carried out with two-stage Anderson sampler from January to December, 2010. Air was sampled monthly at different five zones. 75 fungal spore identified belonging to 23 genera were observed. Out of which the class wise percentage contribution as; zygomycotina (3.22\%), ascomycotina (0.83\%), deuteromycotina (94.22\%) and unidentified spp. (1.73\%) was recorded. Deuteromycotina fungi were most dominant to the total fungal flora. Among them Cladosporiumcladosporieds $\left(1666.2 \mathrm{CFU} / \mathrm{m}^{3}\right)$ followed by Alternariaalternata $\left(981.34 \mathrm{CFU} / \mathrm{m}^{3}\right)$ and Cladosporiumherbarum $\left(896.62 \mathrm{CFU} / \mathrm{m}^{3}\right) \&$ Penicilliumchrysogenum $\left(896.62 \mathrm{CFU} / \mathrm{m}^{3}\right)$. Maximum incidence was observed from February $\left(1595.6 \mathrm{CFU} / \mathrm{m}^{3}\right)$ followed by December $\left(1320.2 \mathrm{CFU} / \mathrm{m}^{3}\right)$ and November $\left(1235.5 \mathrm{CFU} / \mathrm{m}^{3}\right)$. Seasonally there was quantitative aerospora change in the incidence was observed. The total indoor and outdoor fungal spore counts have been statistically no significantly difference ( $t=0.45 ; P>0.05)$ using STATA 11.0 base data analysis with Student ' $t$ ' test.

Keywords: Airborne fungi, Indoor \& Outdoor, Jabalpur, Schools.
\end{abstract}

\section{Introduction}

Aeromycological survey in indoors and outdoors considerably helped to locate the source, its identification, concentration and seasonal variation. Such information, however, provides basic data for the treatment of sensitive individuals suffering from allergy. Many airborne fungal spores are responsible for allergic diseases ${ }^{1}$.

The type and concentration of fungi in buildings differ depending upon the building maintenance, material use in the building, furniture and carpeting, ventilation system, extend of indoor plants, indoor temperature, relative humidity and other abiogenic and biogenic factors including environmental parameters ${ }^{2-4}$. The role of mold concentrations in building environments is important from a clinical point, of view and significant with regards to building hygiene and bio deterioration ${ }^{5}$.

More recently, schools have become the focus of indoor air quality (IAQ) issues. Schools are locations where children spend a large amount of their time, second only to time spent indoors at home ${ }^{6}$.

The objectives of the present work were comparative study on the occurrence of airborne viable fungal spores present in the indoor and outdoor atmospheres of different schools in Jabalpur.

\section{Material and Methods}

Aerobiological Sampling- For the purpose of environmental survey of airborne fungi in schools of Jabalpur city, the city was divided into five different zones viz. North, South, Central, East and West Zones to cover maximum schools. Individual zones cover 12 wards so that all the zones comprised of total 60 wards. One year survey was planned for the estimation of fungal flora in different seasons in schools environment. Air sampling was carried out using Anderson two-stage sampler on (SDA) Sabouroud's Dextrose Agar Media in the schools to determine the viable fungal spore's concentration?

Isolation and Identification-The exposed petriplates were incubated at $27^{\circ} \mathrm{C} \pm 1^{\circ} \mathrm{C}$ and developed colonies were examined after 3-5 days based on their colony characteristics, colour and shape of the colonies developed. Fungal were identified macroscopic and microscopic characters. The identification of different microbes was confirmed by slide culture techniques and consulting standard literature ${ }^{8-12}$.

Statistical Analysis- We analyzed the data obtained by Student' ${ }^{\prime}$ ' test using the software STATA (version 11.0). Microsoft office Excel 2007 had been used for other statistical analysis and graphical representation.

\section{Results}

The chief purpose of the present work was to study the monthly incidence of airborne fungi, seasonal variation and influence of meteorological parameters in indoor and outdoor fungi of Jabalpur city. During the study period, a total number of 10,173 fungal colony forming units $\left(\mathrm{CFU} / \mathrm{m}^{3}\right)$ were isolated from both indoors and outdoors of the schools, of which indoor environments contributed to $51.05 \%$ and the outdoor environments 
to $48.95 \%$. Incidence of airborne fungal species, their $\mathrm{CFU} / \mathrm{m}^{3}$ contribution and annual occurrence recorded in each environment of the schools are given on table- 1 .

In qualitative analysis, altogether 75 fungal species belonging to 23 genera were isolated from both indoor and outdoors. Among these, 6 species of 2 genera belong to zygomycotina, 2 species of 1 genera belong to ascomycotinaand 67 species of 20 genera belong to deuteromycotina were isolated and identified from indoor and outdoors respectively. Among the total number of identified fungal species, Aspergillus was represented by 15 species viz., A. candidus, A. clavatus, A. flavipes, A. flavus, A. fumigatus, A. glaucus, A. nidulance, A. niger, A. parasiticus, A. sp., A. tamari, A. terreus, A. ustus, A. versicolor and A.wentii followed by 10 species of Alternariaviz., A. alternata, A. brassicicola, A. citri, A. dianthi, A. longipes, A. soloni, A. sp., A. tamari, A. tenius and A. Triticiae,6 species of Penicillium viz., $P$. sp., $P$. chrysogenum, $P$. citrinum, $P$. funiculosum, $P$. nigricans and $P$. notatumand 5 species of Curvularia viz., C. brachyspora, C. lunata, C. pallencens, $C$. sp. and C. tiniusfig. -1 .

Monthly incidence of fungal spores with the month of February (16.32\%) contribution of the maximum spore in indoor air. Other months, especially December (15.09\%) and October (11.25\%) were recorded more. Less number of fungal spores is recorded in the month of August (2.86\%). The month of February (15.02\%) contribution of the maximum spore in outdoor air. Other months, especially November (13.53\%) and December (10.77\%) were recorded more. Less number of fungal spores is recorded in the month of April (3.54\%). The highest concentration in indoor environments $\left(5192.63 \mathrm{CFU} / \mathrm{m}^{3}\right)$ and lowest concentration in outdoor environments $\left(4980.83 \mathrm{CFU} / \mathrm{m}^{3}\right)$ fig.-2.

The comparison of the fungal flora recovered from indoor and outdoor revealed no major differences. All the zones put together, 59 from indoors and 65 outdoors were recorded. The analysis revealed that the difference of mean concentration of fungi in 2010 between indoor and outdoor is not significantly different $(\mathrm{t}=0.45 ; \mathrm{P}>0.05)$.

Based on comparative analysis of the occurrence of dominant fungal species with their contribution in indoor and outdoorof the schools, Cladosporiumcladosporieds (16.38\%) contributed maximum in both indoor and outdoor followed by Alternariaalternata $(9.65 \%)$ and Cladosporiumherbarum ( $8.81 \%)$. Data of the annual occurrence revealed that Cladosporiumcladosporieds was the highest with (17.40\%) in indoors and (15.31\%) in outdoors, and Alternariaalternata recorded higher in indoor (11.56\%) than outdoor (7.65\%).

Seasonal occurrence of fungal spores in indoor and outdoor is given in, which shows that the winter season contributed the maximum (46.02\%) followed by summer (32.63\%) and rainy $(21.34 \%)$ in indoor. And in outdoor the winter $(44.64 \%)$ followed by summer $(34.44 \%)$ and rainy $(20.90 \%)$. Over all, winter contributed the maximum fungal spores.

In the present study, zone wise colony forming units $\left(\mathrm{CFU} / \mathrm{m}^{3}\right)$ concentration of fungal species was also analysed, out of total aeromycoflora, North zone $\left(2058 \mathrm{CFU} / \mathrm{m}^{3}\right)$, South $\left(1896 \mathrm{CFU} / \mathrm{m}^{3}\right)$, Central $(1945$ $\left.\mathrm{CFU} / \mathrm{m}^{3}\right)$, East $\left(2178 \mathrm{CFU} / \mathrm{m}^{3}\right)$ and west zone $\left(2097 \mathrm{CFU} / \mathrm{m}^{3}\right)$ were recorded. East zone fungi showed maximum contribution to the total fungal flora followed by West zone and North zone were recorded. South zone fungi showed minimum contribution to the total fungal flora.Class wise percentage contribution as; zygomycotina (3.22\%), ascomycotina (0.83\%), deuteromycotina (94.22\%) and unidentified spp. (1.73\%) was recorded fig.-3.

In Jabalpur, the highest fungal spore concentrations were detected in the winter season when the temperature and humidity provide the optimum conditions for the development of fungi. The decrease in spore concentrations in the rainy season may be related to the, which are not optimum conditions for the growth of fungi.

Table-1, Showing the CFU $/ \mathrm{m}^{3}$ and their \% contribution to the totalnumber of Fungal spores in Indoor and Outdoor of Schools

\begin{tabular}{|c|c|c|c|c|}
\hline \multirow[t]{2}{*}{ FUNGAL ISOLATES } & \multicolumn{2}{|c|}{ INDOOR } & \multicolumn{2}{|c|}{ OUTDOOR } \\
\hline & $\mathrm{CFU} / \mathrm{m}^{3}$ & $\%$ & $\mathrm{CFU} / \mathrm{m}^{3}$ & $\%$ \\
\hline \multicolumn{5}{|l|}{ (A) ZYGOMYCOTINA } \\
\hline Mucormucedo & 70.6 & 1.36 & 74.13 & 1.49 \\
\hline Mucorsp. & 14.12 & 0.27 & 10.59 & 0.21 \\
\hline Rhizopusnigricans & 42.36 & 0.82 & 31.77 & 0.64 \\
\hline Rhizopusoryzae & 17.65 & 0.34 & 17.65 & 0.35 \\
\hline Rhizopussp. & 24.71 & 0.48 & 14.12 & 0.28 \\
\hline Rhizopusstolonifer & 7.06 & 0.14 & 3.53 & 0.07 \\
\hline \multicolumn{5}{|l|}{ (B) ASCOMYCOTINA } \\
\hline Chaetomiumglobosum & 14.12 & 0.27 & 49.42 & 0.99 \\
\hline Chaetomiumsp. & 7.06 & 0.14 & 14.12 & 0.28 \\
\hline \multicolumn{5}{|c|}{ (C)DEUTEROMYCOTINA } \\
\hline Alternariaalternata & 600.1 & 11.56 & 381.24 & 7.65 \\
\hline Alternariabrassicicola & & & 7.06 & 0.14 \\
\hline Alternariacitri & 7.06 & 0.14 & 7.06 & 0.14 \\
\hline Alternariadianthi & 7.06 & 0.14 & & \\
\hline Alternarialongipes & 60.01 & 1.16 & 52.95 & 1.06 \\
\hline
\end{tabular}


Assessment Of The Indoor And Outdoor Mycoflora Of Schools In Jabalpur City, India

\begin{tabular}{|c|c|c|c|c|}
\hline Alternariasoloni & 7.06 & 0.14 & & \\
\hline Alternariasp. & 24.71 & 0.48 & 49.42 & 0.99 \\
\hline Alternariatamari & & & 7.06 & 0.14 \\
\hline Alternariatenius & 7.06 & 0.14 & 3.53 & 0.07 \\
\hline Alternariatriticiae & & & 3.53 & 0.07 \\
\hline Aspergillus candida & & & 7.06 & 0.14 \\
\hline Aspergillusclavatus & 10.59 & 0.2 & 14.12 & 0.28 \\
\hline Aspergillusflavipes & & & 24.71 & 0.5 \\
\hline Aspergillusflavus & 130.61 & 2.52 & 155.32 & 3.12 \\
\hline Aspergillusfumigatus & 120.02 & 2.31 & 165.91 & 3.33 \\
\hline Aspergillusglaucus & 28.24 & 0.54 & 35.3 & 0.71 \\
\hline Aspergillusnidulance & 56.48 & 1.09 & 31.77 & 0.64 \\
\hline Aspergillusniger & 409.48 & 7.89 & 451.84 & 9.07 \\
\hline Aspergillusparasiticus & & & 3.53 & 0.07 \\
\hline Aspergillussp. & 7.06 & 0.14 & & \\
\hline Aspergillustamari & & & 3.53 & 0.07 \\
\hline Aspergillusterreus & 45.89 & 0.88 & 38.83 & 0.78 \\
\hline Aspergillusustus & 17.65 & 0.34 & 3.53 & 0.07 \\
\hline Aspergillusversicolor & 56.48 & 1.09 & 49.42 & 0.99 \\
\hline Aspergilluswentii & & & 3.53 & 0.07 \\
\hline Bisporasp. & & & 3.53 & 0.07 \\
\hline Cladosporiumcladosporoides & 903.68 & 17.4 & 762.48 & 15.31 \\
\hline Cladosporiumelatum & 17.65 & 0.34 & 3.53 & 0.07 \\
\hline Cladosporiumherbarum & 458.9 & 8.84 & 437.72 & 8.79 \\
\hline Cladosporiumsphaeruspermum & 10.59 & 0.2 & 7.06 & 0.14 \\
\hline Curvulariabrachyspora & 3.53 & 0.07 & & \\
\hline Curvularialunata & 271.81 & 5.23 & 285.93 & 5.74 \\
\hline Curvulariapallencens & 10.59 & 0.2 & 31.77 & 0.64 \\
\hline Curvulariasp. & & & 24.71 & 0.5 \\
\hline Curvulariatinius & & & 3.53 & 0.07 \\
\hline Drechslerabicolor & & & 7.06 & 0.14 \\
\hline Drechslerahaweiiensis & 109.43 & 2.11 & 14.12 & 0.28 \\
\hline Drechslerasp. & 52.95 & 1.02 & 49.42 & 0.99 \\
\hline Epicoccumnigrum & 24.71 & 0.48 & & \\
\hline Epicoccumsp. & 3.53 & 0.07 & 7.06 & 0.14 \\
\hline Fusariummoniliformae & 24.71 & 0.48 & 81.19 & 1.63 \\
\hline Fusariumoxysporium & 84.72 & 1.63 & 112.96 & 2.27 \\
\hline Fusariumsoloni & & & 7.06 & 0.14 \\
\hline Fusariumsp. & & & 24.71 & 0.5 \\
\hline Helminthosporiumoryzae & 3.53 & 0.07 & 17.65 & 0.35 \\
\hline Helminthosporiumsp. & 17.65 & 0.34 & 7.06 & 0.14 \\
\hline Monodictysfluctuata & 10.59 & 0.2 & 10.59 & 0.21 \\
\hline Nigrosporaoryzae & 21.18 & 0.41 & 24.71 & 0.5 \\
\hline Nigrosporasp. & 24.71 & 0.48 & 42.36 & 0.85 \\
\hline Nigrosporaspaerica & 7.06 & 0.14 & & \\
\hline Penicilliumsp. & 35.3 & 0.68 & 52.95 & 1.06 \\
\hline Penicilliumchrysogenum & 437.72 & 8.43 & 458.9 & 9.21 \\
\hline Penicilliumcitrinum & 109.43 & 2.11 & 158.85 & 3.19 \\
\hline Penicilliumfuniculosum & & & 3.53 & 0.07 \\
\hline Penicilliumnigricans & 458.9 & 8.84 & 317.7 & 6.38 \\
\hline Penicilliumnotatum & 45.89 & 0.88 & 31.77 & 0.64 \\
\hline Phomaherbarum & & & 7.06 & 0.14 \\
\hline Phomasp. & 3.53 & 0.07 & & \\
\hline Rhizoctaniabatalicolor & 21.18 & 0.41 & 45.89 & 0.92 \\
\hline Scopulariopsissp. & 31.77 & 0.61 & 28.24 & 0.57 \\
\hline Scytalidiumsp. & 74.13 & 1.43 & 67.07 & 1.35 \\
\hline Stachybotrysatra & 3.53 & 0.07 & & \\
\hline Stemphyliumsp. & 7.06 & 0.14 & & \\
\hline Torulaellisi & & & 21.18 & 0.43 \\
\hline Torulasp. & 7.06 & 0.14 & & \\
\hline Trichodermasp. & 3.53 & 0.07 & & \\
\hline Trichodermaviridae & 7.06 & 0.14 & 21.18 & 0.43 \\
\hline Unidentified spp. & 91.78 & 1.77 & 84.72 & 1.7 \\
\hline Grand Total & 5192.63 & 100 & 4980.83 & 100 \\
\hline
\end{tabular}

\section{Discussion}

Theaeromycoflora of the 60 schools that were taken in to consideration for study had a distinct structural and location difference. In case of the schools building is more than two decades old without proper ventilation and maintenance. Thus in the process most of the class rooms remain humid for several months in the year, representing a typical sick building syndrome.

Singh and her coworkers ${ }^{13}$ recorded 39 fungal species, among which Cladosporiumranked first followed by Aspergillus and Penicillium in Delhi. Agashe and Anuradha ${ }^{14}$ also opined the dominance of 
Cladosporium followed by Aspergillus and Alternaria during their work in Bangalore. Cellulose degrading fungi, Trichoderma and Chaetomiumglobosum recorded in the present study are well known fungi to be available in the books and papers ${ }^{14,15}$. Aspergillusniger and Aspergillusfumigatus cause respiratory infection leading to bronchopulmonary aspergillosis ${ }^{16,17}$. Aspergillusflavus, a well known fungus for production of aflatoxin, causes asthma in workers of indoor environments ${ }^{18}$. Penicilliumspp. are known for allergencity and are the cause allergic alveolities ${ }^{19}$. AlthroughAlternariaalternata was not abundantly recorded, it is accounted asa human allergens for sporosisinducer, an agent for hay fever and other pathologies ${ }^{20}$.

This study revealed exhibition of marked seasonal periodicity by the fungal propagules in the atmosphere of Jabalpur city.

Peak monthly spore count was observed in February followed by October to December count was the least in April and August months more similar monthly profile has been reported by Rao and Mallaiah ${ }^{21}$. Peak counts of fungal spores were observed in December in Thailand ${ }^{22}$, two peaks in February- March and OctoberNovember in Malayasia ${ }^{23}$.

\section{Conclusion}

The one-year air monitoring in schools of Jabalpur revealed presence of rich fungal flora throughout the year. Alternaria, Aspergillus, Curvularia, Cladosporium and Penicillium were the dominant fungal spore groups. All dominant spores are reportedly allergic though the threshold concentration of these spores to become the potential allergens is not yet defined.

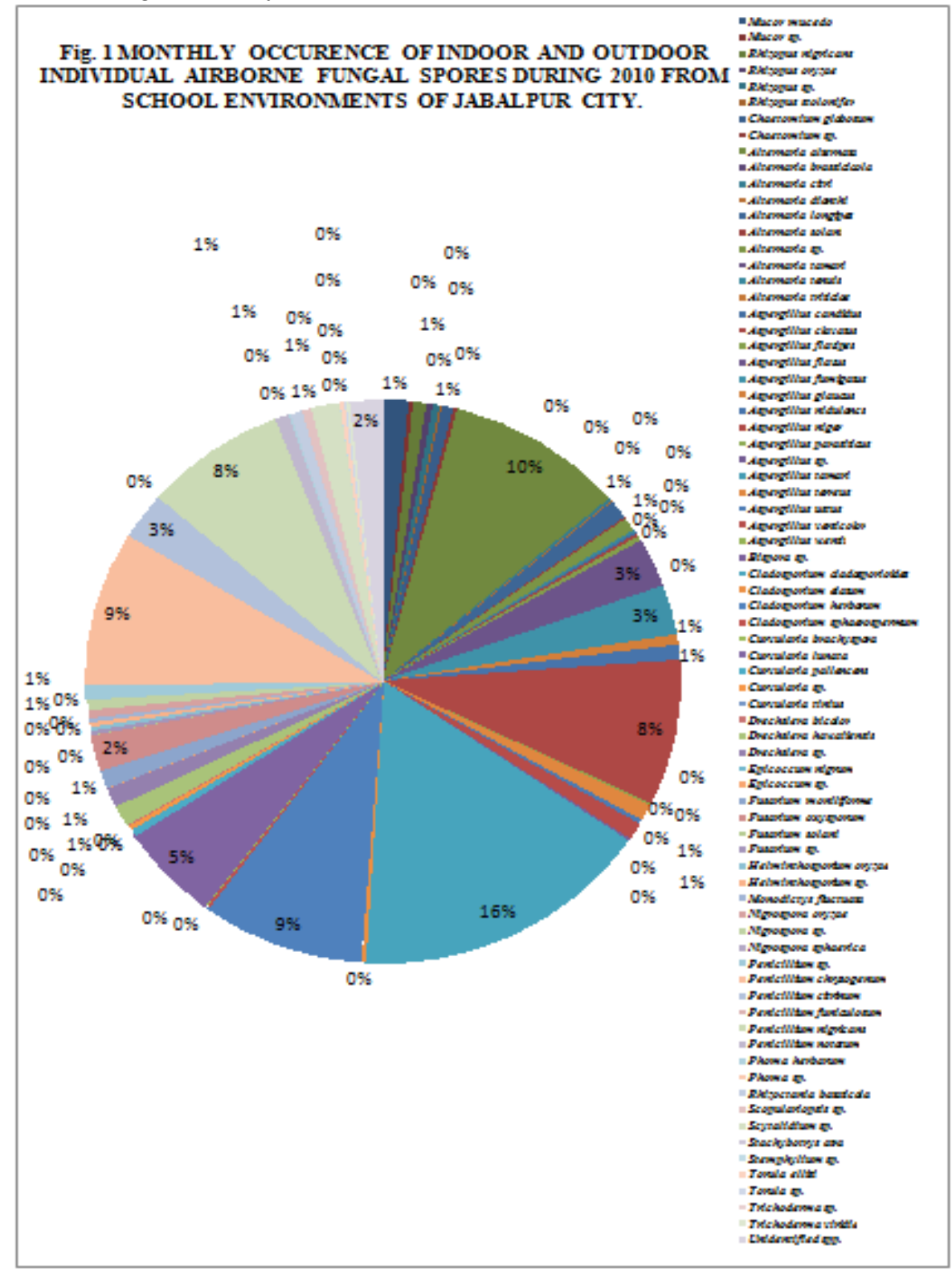




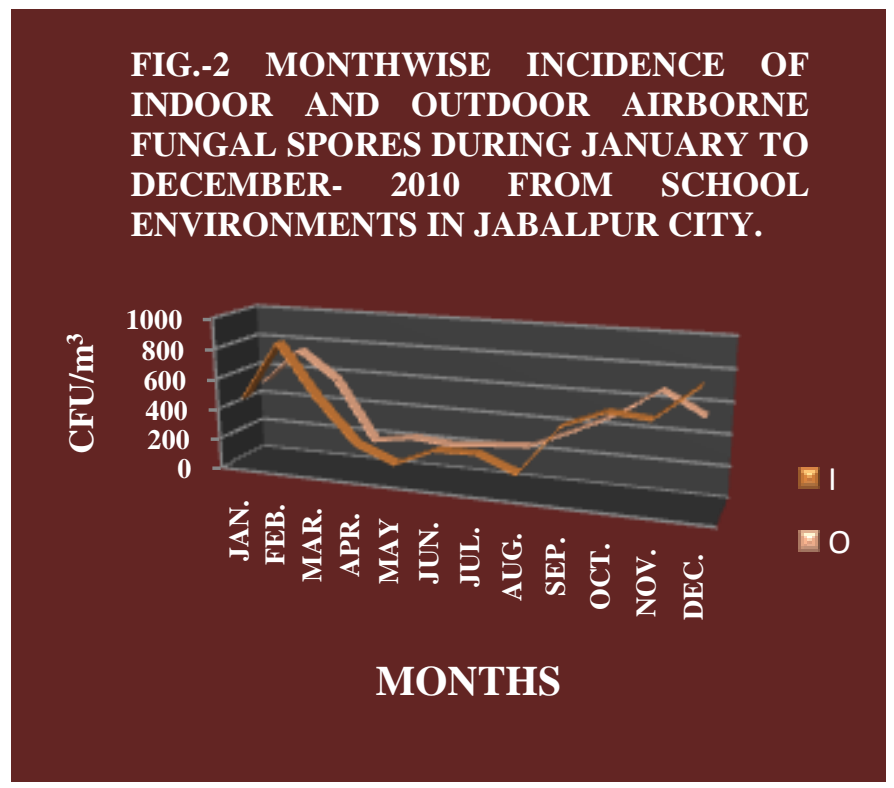

\title{
FIG.- 3, FUNGAL AIRSPORA TRAPPED \\ ON THE VARIATION OF CLASSWISE 2010.
}

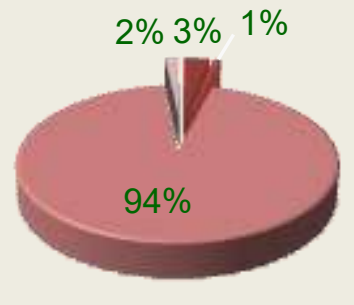

\author{
Zygomycotina \\ Ascomycotina \\ Q Deuteromycotina \\ $\square$ Unidentified spp.
}

\section{Acknowledgement}

I am thankful to Head Department of Biological Science, Rani Durgavati University, Jabalpur for her inspiration and providing facilities to carry out the investigation.

\section{References}

[1]. Tilak, S.T. 2010. Aerobiology to Astrobiology. BharatiVidyapeeth Scientific Monograph No. 1.

[2]. Kozak, P.P., Gallup, Cummins, L.H. and Gillman, S.A. 1979. Factors of importance in determining the prevalence of indoor fungi. Ann. Allergy. 43:88-94.

[3]. Pieckora, E. and Jesenska, Z. 1999. Microscopic fungi in dwellings and their health implications in humans. Ann. Agric. Environ. Med. 6:1-11.

[4]. Flannigan, B. and Miller, D.J. 2001. Microorganisms. In Home and Indoor Work Environments. Diversity, Health Impacts, Investigation and Control.35-67. CRS Press, Boca Raton FL.

[5]. Sahay, R., Parvataneni, S., Barnes, R., Aguirre, F., Wozniak, A., Singh, A.B. and Gasana, J. 2008. Assessment of Surficial Mould in Indoor Environments. Indian J. Aerobiol. 21(1):13-23.

[6]. Moglia, D., Smith, A., MacIntosh, D. and Somers, J. 2006. Prevalence and implementation of iaq programs in U.S. schools. Environmental Health Perspective.114: 141-146.

[7]. Anderson, A.A. 1958. New sampler for the collection sizing and enumeration of viable air borne particles. J. Bact.76:471-484.

[8]. Barnett, H.L. 1960. Illustrated genera of Imperfect fungi Minn:Burges publishing Co. New York.

[9]. Tilak, S.T. 1998. Aerobiology. VaijayantiPrakashan, Aurangabad. 212.

[10]. Ellis, M.B. 1971.DematiaceousHyphomycetes. Common Wealth Mycological Institute, Kew. Surrey, England.

[11]. Ellis M.B. 1976. More DematiusHyphomycotes. Common Wealth Mycological Institute Kew, Survey England.

[12]. Gilman, J.C. 1975. A Manual of Soil Fungi, Oxford and IBH Pub. Co., New Dehli.

[13]. Singh, A. Gauguli, M. and Singh, A.B. 1995. Fungal spores are an important components of library air. Aerobiologia. 11:231-237.

[14]. Agashe, S.N. and Anuradha, H.G. 1998.Aeromycological studies of a library in Banglore. Indian J. Aerobiol. 11:24-26.

[15]. Tripathi, R.N. 1987. Fungal air-spora inside the central library of Gorakhpur University Water, Air and Soil Pollution. 34:125-134. Vittal B.P.R., Shaik K.R. 1995 
[16]. Katz Y., Verleger H., Barr J., Rachmiel M., Kiviti S. and Kuttin E.S. (1999) Indoor survey of moulds and prevalence of mould atopy in Israel. Clin. Exp. Allergy. 29(2):186-92.

[17]. Topping, M.D., Scarisbrick, D.A., Luczynska, C.M., Clarke, E.C. and Seaton, A. 1985. Clinical and immunological reaction to Aspergillusniger among workers at a biotechnology plant. Br. J. Ind. Med. 42:312-318.

[18]. Nanda, A., Nayak, B.K. and Behera,N. 2000. Allergenic Bioaerosols in Indoor Environments of Roral Houses. Environment, Health and Development. Ed:P. Dash Sharma: Ranchi. 35-50.

[19]. Cardasco, E., Demeter, S. and Zenz, C. 1995 Environmental respiratory diseases. Ed \& Pub: New York: Van Nostrand Reinhold.

[20]. Burge, H.A. 1985. Fungus allergens. Clin. Rev. Allergy. 3:319-329.

[21]. Rao, P.S.S. and Mallaiah, K.V. 1988. Airborne fungal spore at Nagarjun Nagar. Proc. Indian Acad. Sci. (Plant Sci.). 98:191-197.

[22]. Phanichyakarn, P., Kraisarin, C. and Sasilakulporn, C. 1989. Atmospheric pollen and mold spores in Bangkok: a 15-year survey. Asian Pacific J. Allergy Immun. 7:113-118.

[23]. Ho, T.M., Tan, B.H., Ismail, S. and Bujang, M.K. 1995. Seasonal prevalence of airborne pollen and spores Kuala Lumpur, Malaysia. Asian Pacific J. Allergy Immun. 13:17-22. 